
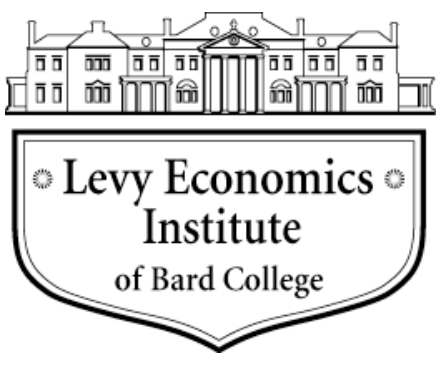

Working Paper No. 860

\title{
Looking Into the Abyss? Brazil at the Mid-2010s
}

by

Fernando J. Cardim de Carvalho

Levy Economics Institute of Bard College

February 2016

The Levy Economics Institute Working Paper Collection presents research in progress by Levy Institute scholars and conference participants. The purpose of the series is to disseminate ideas to and elicit comments from academics and professionals.

Levy Economics Institute of Bard College, founded in 1986, is a nonprofit, nonpartisan, independently funded research organization devoted to public service. Through scholarship and economic research it generates viable, effective public policy responses to important economic problems that profoundly affect the quality of life in the United States and abroad.

\author{
Levy Economics Institute \\ P.O. Box 5000 \\ Annandale-on-Hudson, NY 12504-5000 \\ http://www.levyinstitute.org
}

Copyright (C) Levy Economics Institute 2016 All rights reserved

ISSN 1547-366X 


\section{ABSTRACT}

The Brazilian economy in 2015 was afflicted by a lethal combination of decelerating activity and accelerating inflation. Expectations for 2016 are equally or even more adverse, since the effects of rising unemployment emerge only after a lag. The domestic debate has pitted analysts who believe the crisis is due exclusively to past policy mistakes against those who believe that all was well until the government decided to implement austerity policies in 2015. A closer examination of the evidence shows that, in fact, both causes contributed to the crisis. But it also suggests that its depth has a more proximate cause in the political collapse of the federal government in 2015, which led Brazilian society to an impasse for which one cannot yet visualize the solution.

Keywords: Brazilian Economy; Macroeconomic Policy; Great Recession

JEL Classifications: E31, E32, E60 


\section{INTRODUCTION}

Brazilian real GDP is estimated to have contracted 3.8\% in 2015. Projections for 2016 are only marginally better: the IMF projects a further contraction of 3.5\% (IMF 2016). Annual inflation reached $10.7 \%$ in $2015,{ }^{1}$ way above the targeted rate of $4.5 \%$ or even the ceiling of the policy band of 6.5\%. The overnight cost of bank reserves in the interbank market (SELIC) is currently $14.25 \%$ p.a. The exchange rate to the US dollar is around $\mathrm{R} \$ 4$, a $50 \%$ increase over a year ago. Fiscal space for implementing recovery policies is practically nonexistent, with fiscal deficits reaching $10.3 \%$ of GDP and gross public debt ratio to GDP at $66.2 \% .^{2}$ Unemployment has been growing rapidly and perspectives for 2016 are not promising, to say the least. Concerns about the solvency of large firms, which have sharply increased their foreign indebtedness in recent years, have intensified with the steep devaluation of the real in 2015.

Managing such a situation would be a tall order even for an efficient administration that could count on popular support. Alas, the current administration cannot count on popular support. Approval rates for the president have consistently stayed in the single digits since the beginning of 2015. The president is considered by many of her supporters to have betrayed the election promises of 2014. Besides, a large share of the population seems to believe the administration to be hopelessly tainted by large-scale corruption. The most important of these scandals has all but destroyed the largest firm in the country, Petrobras, the oil company of which the federal government is the largest stockholder. ${ }^{3}$ The president is currently facing an impeachment process, but the Chairman of the Chamber of Deputies (who initiated the process and is the third in the line of succession) is himself widely expected to go to jail in the near future for his own role in large-scale corruption schemes. An unusually high degree of uncertainty, even for local standards, surrounds predictions of who is going to be "in charge" in the near future and how whoever ends up assuming the presidency (including Rousseff herself) will be able to govern.

\footnotetext{
${ }^{1}$ Cf. Ipeadata, Inflação: IPCA (http://www.ipeadata.gov.br/).

${ }^{2}$ Cf. Banco Central do Brasil, Nota para a Imprensa: Política Fiscal, 01/29/2016 (http://www.bcb.gov.br/?ECOIMPOLFISC). The debt/GDP ratio may not be considered excessive, especially if one compares it with the ratios exhibited by advanced economies in the post-crisis period. Moreover, it is important to keep in mind that public debt is mostly denominated and payable in local currency. Nevertheless, the pace at which debt has been growing lately and the wide use of accounting tricks by the government to disguise it powerfully eroded public trust in the federal government, constraining its fiscal policy choices.

${ }^{3}$ In fact, Petrobras is not just an oil company. The company was created as a result of intensely nationalistic feelings in the early 1950s manifested in mass demonstrations and even violent conflicts with the government. To many it is in fact a symbol of nationhood.
} 
President Rousseff was inaugurated for her second term on January 1, 2015. The transition for the second term was unexpectedly turbulent. ${ }^{4}$ The president had in fact fired her finance minister in July 2014, when she announced in a press interview that she would not keep him in the government in the second term. The replacement, however, was only announced in December, after the decisive second ballot. ${ }^{5}$ The new minister made public that he would seek to implement a tough austerity program in 2015. The president tried unsuccessfully to characterize the move as a natural evolution of her overall economic strategy - that is as a temporary adjustment necessary to allow her to resume her growth policies later.

Predictably, the ambiguity of her position caused it to be rejected by supporters and opponents alike. For the former, there was no way to circumvent the fact that she was reneging on her campaign commitments. For the latter, the adjustment was admittedly a farce, an artifice to disguise the continuing implementation of mistaken economic policies.

Counting on, at best, lukewarm support from her political base in the face of the aggressive attack from a rejuvenated (if rather unprincipled and fragmented) opposition, the newly installed administration did not have any chance to move one way or the other in 2015. Very early on, Congress showed its unwillingness to consider the proposals presented by the president or to give them any priority. When the eventuality of initiating impeachment procedures against the president became a concrete possibility, the government was paralyzed, and has remained paralyzed ever since.

Whether or not the president remains in power, which should probably be decided in the first half of 2016, the fact remains that the problems facing the Brazilian economy are real and urgent and the degrees of freedom to design consistent policy responses for whomever ends up in power are limited.

\footnotetext{
${ }^{4}$ In fact, since the president was reelected, even the idea of transition may sound strange. The president, however, announced policies that totally contradicted her campaign rhetoric to such an extent that for all purposes one could consider it a new government.

${ }^{5}$ Elections for executive posts (president, state governors, and mayors) take place in two rounds. In the first, all candidates can run. If none of them obtains $50 \%$ plus one votes, there is a second round where only the two leading contenders run.
} 


\section{HIGH INFLATION}

It is easy for foreign observers, unfamiliar with Brazil's recent history, to underestimate the problems created by high rates of inflation and the strength of the sensitivity of the population to risks of inflation rising out of control. ${ }^{6}$ We are obviously far away from the experiences with high inflation of the 1970s to the 1990s. Nevertheless, the memory of their personal experiences with high inflation is still strong for most of the current adult population: the loss of reference for relative prices, the shortcomings of indexation to preserve one's real income, the uncertainties about one's solvency in the immediate future, etc. People who lived through the period become very anxious whenever there is any sign that governments are being lenient with inflation or unable to control it. For individuals, being inert is simply not an option. If the government cannot fight inflation, private agents tend to turn to indexation to protect themselves (there is no tradition of the practice of dollarization in the country). Even though the memory is also still fresh that indexation was not an "optimal" solution in any sense, and it could not in fact keep real incomes stable, it still could attenuate the damage caused by rapidly rising prices.

Thus, controlling inflation is an inescapable demand made of every government elected after the success of the 1994 stabilization plan. Of course, controlling inflation is particularly difficult when, as it is currently the case: 1) output and employment are falling; and 2) political instability is so acute that no cooperative solutions can be found to allocate the losses caused by an anti-inflationary policy.

Table 1 shows the evolution of the consumer price index (IPCA), which is used by the central bank to orient its interest rate decisions.

\footnotetext{
${ }^{6}$ An examination of the damage imposed by high inflation regimes and the difficulties of switching to a low inflation regime is presented in Feijo and Cardim de Carvalho (1992). The attitude of the Germans with respect to risks of an inflationary push, supposedly inspired by their experience with a hyperinflation in the 1920s, illustrates how long these feelings can survive in the collective memory of a country.
} 
Table 1: Consumer Price Index

\begin{tabular}{|l|r|}
\hline \multicolumn{2}{|l|}{ IPCA-Annual } \\
Variation (in percent)
\end{tabular}

Source: Ipeadata

The last time the inflation rate was (barely) contained below the target of 4.5\% was 2009 . Between 2009 and 2014, the rate increased slowly but it still remained within the policy band, the ceiling of which is $6.5 \%$. In 2015, however, the annual inflation rate was $10.7 \%$, which is $66 \%$ higher than that of 2014 , more than double the target rate. Inflation has accelerated mostly because of three factors: 1 ) supply shocks; 2) the need to adjust the prices of utilities; and 3) inertial mechanisms.

Two kinds of supply shocks in the last three years have strongly pushed prices up. On the one hand, Brazil has suffered a series of natural shocks in the form of droughts and floods, frequently at the same time, in different regions of the country. Weather instability hit food prices almost continuously in the period. Moreover, a prolonged drought in 2014 (which extended into 2015) pushed energy prices sharply up in a country that is heavily dependent on hydropower. The fall in water levels in dams and reservoirs forced producers to switch to thermal electric plants, for which the cost of operation is much higher than in hydropower generation. The government tried to weaken or disguise the cost pressures by subsidizing the operation of firms in the sector for a while, but it was a short-lived artifice: It increased fiscal expenditures and stimulated private agents to keep their energy consumption coefficients unchanged. When the drought was revealed to be intense and long lasting, the government could not sustain the policy of subsidies and had to increase energy prices sharply in 2015. These prices, of course, not only reduced consumers' real income, but also represented a significant cost increase for all firms. To the extent that the latter were able to shift their increased costs to buyers, inflationary pressures spread throughout the economy. 
However, a second supply shock, having nothing to do with natural causes, also had an important influence on the behavior of prices. Upward exchange rate instability, which began with Fed Chairman Bernanke’s “tapering” announcement, was intensified by subsequent bad news coming from practically all corners of the world, including Brazil itself. In fact, exchange rates have been volatile around this increasing trend that has substantially increased domestic prices not only of imported goods but of tradables in general.

The devaluation of the domestic currency, the real, is particularly important for two reasons: 1) since the monetary reform that created the real, exchange rate appreciation had been a central tool of anti-inflation monetary policies; and 2) an exchange rate devaluation pushes domestic prices up, thereby relieving (at least in part) the pressures on those domestic producers who have to face competition from imported goods. A situation in which the domestic currency seems to be condemned to a permanent devaluation (the trend underlying observed volatility) may allow the domestic manufacturing sector be revived at the cost of attenuating or even eliminating perhaps the most efficacious tool of inflation control utilized in the post-1994 period.

If one cannot count on exchange rate appreciation to help reduce prices, its stabilization, even if at the high level currently observed, means that one should not expect relevant further pressures coming from this factor in the near future (except, of course, in the case of a collapse of Brazil's balance of payments, a case in which these considerations would not be particularly important anyway). In other words, on balance, the behavior of exchange rates may be near the point where their deleterious influence on inflation may be more than compensated for by its positive influence on reviving domestic manufacturing production.

As to the "natural" supply shocks, the country was obviously unprepared for the intensification of the weather problems it has faced in recent years. Extreme weather has become much more frequent than in the not-so-distant past. Traditional policies, such as keeping regulatory inventories of grains, probably do not help much against variations in the production of perishables, which are more dramatically hit by extreme weather. Increasing imports is also not possible for such goods in many cases, especially in the scale demanded by Brazilian consumers. More durable and efficient solutions would involve technical progress in the production of these goods to make it more independent of natural conditions, 
but we cannot expect such improvements to be introduced in the short to medium term in the scale necessary to make any real difference.

The next factor in explaining recent inflation acceleration is, to some extent, similar in its impact on costs to supply shocks. Differently from the kinds of supply shocks just discussed, however, these pressures are generated by policy mistakes rather than natural causes or events beyond the control of domestic policymakers. As we have already observed, prices of electricity were manipulated long enough to cause significant imbalances to emerge both in terms of producers' solvency and of missed demand adjustments. The "policy,” however, was not confined to electric power. Prices of utilities in general were the object of similar manipulations.

Utility prices are regulated by the state. In a few cases, when the service is run by the state, prices are set by administrative decision. In most cases, however, services are provided by firms of which the state is the majority stockholder or by private groups in the privatized sectors. In its wider sense, utilities include oil and its derivatives, electric power, and public transportation, besides other activities, such as management and maintenance of ports, airports, highways, etc. In all of them, the state has a major influence on pricing policies either as a regulator or as a provider. In the most important ones, the government held prices down to reduce measured inflation for about two to three years.

In the case of oil, the meddling is due, to some extent, to a difficulty in understanding that Petrobras is in fact a firm where the state is the biggest stockholder and not a state entity. It works as a private firm, subject to laws and regulations that define its operation, as well as the powers of its administration and limits to the power of major stockholders (to protect the interests of minority investors). ${ }^{7}$

During Rousseff's first term in office, prices of utilities under the government's (legitimate or illegitimate) direct control were manipulated to reduce inflationary pressures. In her first years in office, with the economy growing more or less robustly, prices of services were mainly responsible for rates of inflation remaining above target. Unable to reduce inflation without threatening to cool down the economy, the government decided to keep utility prices

\footnotetext{
${ }^{7}$ Petrobras sells stocks in foreign markets to investors who expect those rules to be followed on the part of its management. In fact, the firm is currently being sued in US courts precisely for having allegedly broken those rules, among other wrongdoings.
} 
down by whatever means possible. ${ }^{8}$ This "policy” was implemented more strongly in the energy sector, because of its multiplier effects on other prices. Petrobras's accumulated losses during a period of rising oil prices in international markets due to its being prevented from raising its prices. Electric power prices were also kept down, even during the longduration drought already mentioned. Firms operating in these sectors had to be supported by public subsidies to avoid capital losses. As it became well-known, in the case of Petrobras this was not enough, and the losses the firm suffered threaten its survival in the present.

The situation became unsustainable by 2014, and was one of the reasons of Rousseff's change in policies after she was reelected. To eliminate subsidies, energy prices had to be substantially increased, pushing prices generally upwards. Again, one could expect some relief in the near future, as most of the price rises already happened. Optimism has to be guarded, however. Important hysteresis effects may be in operation. Petrobras's poor current state is a strong illustration of such effects, even though, in this case, many other elements conspired to cause its downfall, including continuing corruption at its highest levels. Artificially lower prices for oil derivatives meant that alternative energy sources, such as alcohol (let alone nontraditional sources) were practically written off. Demand for oil and for electricity was maintained at high levels during periods in which it should be reduced or reoriented to alternative sources.

The inflationary impact of the manipulation of utilities prices may become less important from this point on. The deleterious impact of years of wrong policies on the productive structure of the country, however, may take much longer to be neutralized.

Finally, we have to consider the influence of inertial factors. It should cause some surprise, perhaps, to find the inclusion of an inertial factor among the elements explaining the recent acceleration of inflation. Inertial factors, in principle, have to do with propagation rather than acceleration of inflation; however, inertial mechanisms such as indexation of incomes and contracts in fact tend to have an amplified impact on inflation rates for two reasons. Let us assume, to simplify the point, that standard inflationary pressures are random and shortlived. Indexation mechanisms will make their impact durable by transmitting them to incomes and contracts. Indexation thus transforms temporary rises in prices into permanent

\footnotetext{
${ }^{8}$ This much was explained in a newspaper interview by a member of Rousseff's cabinet, adding (curiously) that this was what he thought to be the meaning of the expression "administered prices."
} 
floors to inflation so that new price increases will be added to this floor to determine the current rate of inflation. ${ }^{9}$

Secondly, indexation transforms rises in prices that could go unnoticed by individual firms and persons into active pressures to further increases prices. If indexation takes general price indexes as references, it will adjust incomes and contract values even to price changes that individuals do not perceive or that are not actually relevant for them. ${ }^{10}$

Inflation stabilization was achieved in Brazil with the Real Plan of 1994. The core of the Real Plan was precisely to break with the generalized indexation that characterized the economy in the early 1990s. The break, however, was not complete. In fact, in recent years indexation was even reinstated in the case of some key prices. Of particular relevance to the behavior of inflation is the indexation of some utilities prices in sectors that were privatized in the 1990s and the overindexation of minimum wages, initiated by Rousseff's predecessor, Lula da Silva.

Privatization contracts included guarantees that buyers would not be subject to political manipulation of utilities prices (as in fact ended up happening in the case of Petrobras, as already noted). But those prices were indexed by general price indices, most commonly the Commodities General Price Index, which is supposed to reflect more accurately the behavior of prices of raw materials at wholesale markets. The problem with this practice should be obvious (especially given Brazil's extensive past experience with this type of indexation). Indexing prices by general indices does not intend merely to allow prices to evolve with costs (as it would be the case if prices were indexed, for instance, to costs) but, in principle, to ensure stability of its relative position to other prices, thus freezing relative prices. ${ }^{11}$ This implies that any price increase is transmitted to other prices, no matter how tenuous the

\footnotetext{
${ }^{9}$ This happens if one assumes that the time interval between adjustment of contract values is fixed. When inflation rises beyond a certain point, however, agents try to protect themselves against the loss of real income by reducing the time between adjustments. The shortening of adjustment intervals, everything else the same, accelerates inflation (Cardim de Carvalho 1993).

${ }^{10}$ In some situations, one can argue that this could actually reduce the force of inertial factors. If idiosyncratic factors cause a sharp increase in price, but the remaining prices remain more or less stable, indexation would dilute the force of the idiosyncratic factors. This is not likely to be the case when inflation is rising beyond a certain threshold. Reasons for that are given in Cardim de Carvalho (1993), exploring implications of Frenkel (1979). One also has to remember that existing indexation systems are also asymmetric: values rise with the increase in price indices, but do not fall when indices eventually fall.

${ }^{11}$ This result is not always attained because of the influence of factors like the timing of price adjustments, which allow some variation of relative prices in between adjustments that cannot be compensated for by simple indexation rules.
} 
relationship between those markets may be. Any local pressure that emerges becomes a force to raise the general level of prices of utilities (which are then reflected in the costs of every sector that uses them, raising the prices of the goods they produce).

The other key price that has been reindexed is the minimum wage. Minimum wages have been set by the government since their creation during Getulio Vargas's presidency and their history of manipulation has been almost as long. During the military regime (1964 to 1985), they were manipulated to keep production costs down. Afterwards, civilian governments tried to follow fairer adjustment rules but the acceleration of inflation made their impact uncertain. During his first term in 2003, President Lula da Silva decided to seek the increase of the real minimum wage. Minimum wage adjustments are currently set by a formula that combines past inflation and real GDP increases (rates of growth of total real GDP, not of productivity or per capita GDP). Added to the result obtained by the formula is a small premium decided on by the federal government. The idea behind the initiative, which is correct in itself, is that the minimum wage is an important variable explaining labor income concentration and had been perversely manipulated in the past to lower the cost of labor and increase profits.

Minimum wages did increase during Rousseff's first term, much ahead of average wage rates, even though sectors where unions are stronger could also get wage increases above inflation. There is also evidence that profits in the non-financial sector were decreased for most of the period, especially in the manufacturing sector, where prices have largely been set by international markets. The point, of course, is how far one can go with such redistributive policies by fiat. Paolo Sylos-Labini, in his studies of the Italian economy in the 1960s and 1970s, tried to determine what the "optimal” rate of increase of (real) wages was. On the one hand, increasing wages raise demand for wage goods, which is an increasingly elastic concept nowadays when workers can acquire durable consumer goods on credit. On the other hand, Sylos-Labini pointed out, when real wages increase more than labor productivity profits are reduced and, with them, sooner or later, investments. In Brazil, opposing sides in the debate on minimum wages seem to look at only one effect, neglecting the other. Besides, Sylos-Labini's focus on the real wage itself neglects the possibility that the increase in wages may simply be an important cause of accelerating inflation (Sylos-Labini 1984). ${ }^{12}$

\footnotetext{
${ }^{12}$ Since the minimum wage formula is applied with a relatively long lag in the case of Brazil, it may contribute to increasing unemployment when GDP is falling rapidly but wages are still rising, by force of law.
} 
Eliminating indexation is essential to bringing the inflation rate down, but this is much easier said than done. Removing indexation rules from privatization contracts would demand a renegotiation of contracts, always a difficult matter, particularly when it affects foreign firms. Eliminating minimum wage indexation rules is less a legal problem than a political problem. Not surprisingly, it is almost impossible for a government headed by a worker's party to do it. ${ }^{13}$

If the government cannot deal with supply shocks, exchange rate devaluation, and indexation rules, what room is left for anti-inflationary policy? Only the "free" prices sector in the economy, which mostly means the services sector. Of course, services are as heterogeneous in Brazil as in any other economy. Financial services prices, for instance, are as “administered” as the prices of manufactures. Specialized services, as in health care, also charge administered prices. ${ }^{14}$ At the end of the day, really free prices are only those of services provided by independent “entrepreneurs” (ranging from car mechanics, manicures, barbers, etc., to medical doctors, dentists, etc.), or by entities operating in more competitive markets, such as commerce and private education. These services are highly income-elastic and are the most obvious candidates to be affected by contractionary monetary policy, to the extent that monetary policy can actually help to contract the economy.

If one cannot really expect much from the direct impact of monetary policy, what about the indirect effect, through its impact on inflation expectations? We cannot get too much here into so difficult a subject as how expectations are formed and how to they influence actual behavior. Nevertheless, it is clear that in most cases inflation expectations are closely intertwined with output expectations. Bets on the price-stabilizing effect of monetary policy are in fact bets on its ability to cause enough damage to the economy to break rising trends of wages and prices. Achieving adequate inflation expectations would help monetary policy to break them without having to actually cause too much damage. An important element of such favorable expectations, of course, has to be a belief in the ability of the central bank to inflict sustained damage if necessary. To make things more complicated for the monetary authority, the political crisis that reached its peak in 2015 (and is still far from a resolution) has all but paralyzed economic policymaking everywhere else in the federal government.

\footnotetext{
${ }^{13}$ Right after Rousseff's reelection in late 2014, one of her appointed ministers declared to the press that the law had to be adjusted to the new times. The president publicly demanded his recantation, which he did immediately. The law was renewed and its last application raised minimum wages for 2016, a time of economic decline, by $11.6 \%$.

${ }^{14}$ In fact, in the case of private health plans, annuities are indexed to general price indices, too.
} 


\section{FALLING OUTPUT}

GDP fell sharply in 2015, opening a sharp exchange of views as to what caused the fall. The most obvious candidate, of course, are the austerity policies announced by the finance minister Rousseff appointed for her second term; however there may be much more to this story.

Public debate about the recent performance of the Brazilian economy relies on the notion that it recovered fairly quickly from the 2008-09 recession induced by the shock waves of the Lehman Brothers failure and had successfully maintained its growth momentum until 2014. Reality was somewhat different. The "Chinese growth rate” Brazil reached in 2010 (7.5\%) was an isolated phenomenon. Part of it was in fact mere recovery from the fall in 2009, not the beginning of a new trend, as many people seemed (or wished) to then believe. Afterwards, growth rates initially fell to their “normal” level. By 2011-12, the economy had already lapsed into virtual stagnation, despite the continuing implementation of so-called countercyclical policies. As one can see in figure 1, quarterly growth of GDP was faltering then and ceased completely in 2012. One can debate whether the 2010 recovery was due to the particular choice of countercyclical policies chosen by then-president Lula da Silva or to China maintaining its imports from the Brazilian economy, but whatever worked in 2010 was no longer working so well a little later and stopped working all together by $2012{ }^{15}$

Figure 1: Real GDP Index (Quarterly Levels)

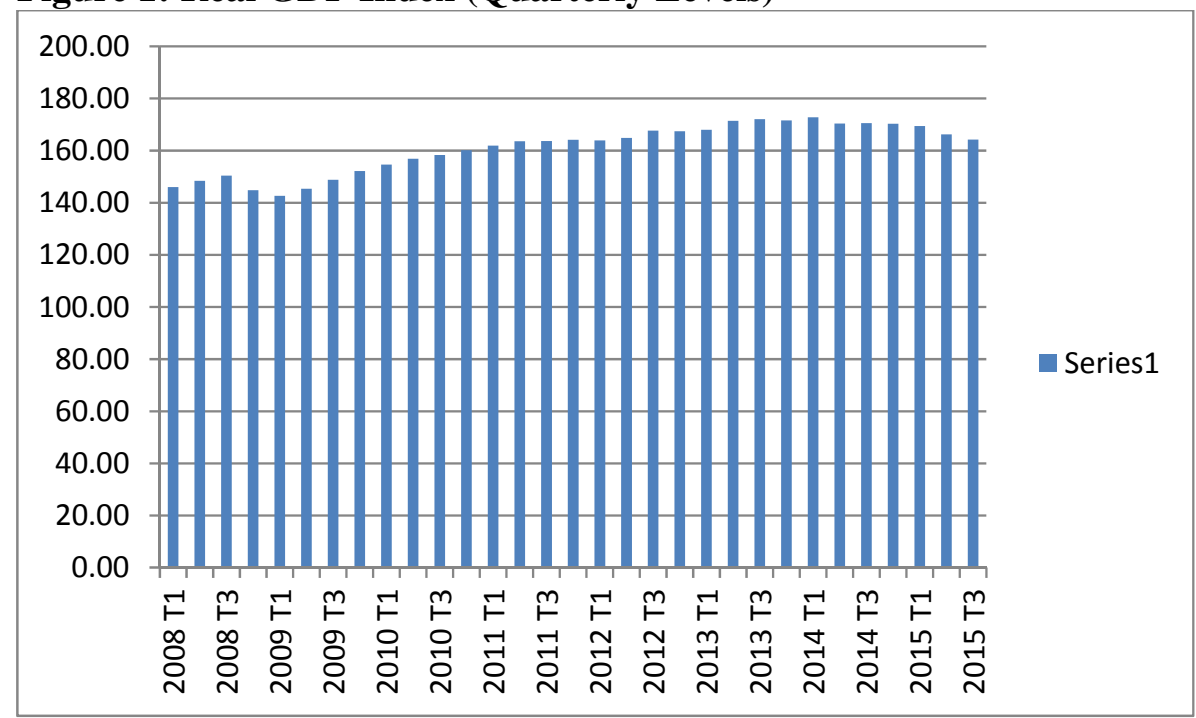

Source: Ipeadata

${ }^{15}$ Kregel (2009) already pointed out significant fragilities of the Brazilian growth strategy. 
One piece of evidence to suggest a minor role to the countercyclical measures adopted was the poor performance of the manufacturing sector, towards which most of the policies were directed. The sector, which does not have China as an important market, barely registered a recovery at all (see figure 2 ). ${ }^{16}$

Figure 2: Real Manufacturing Output Index (Quarterly Levels)

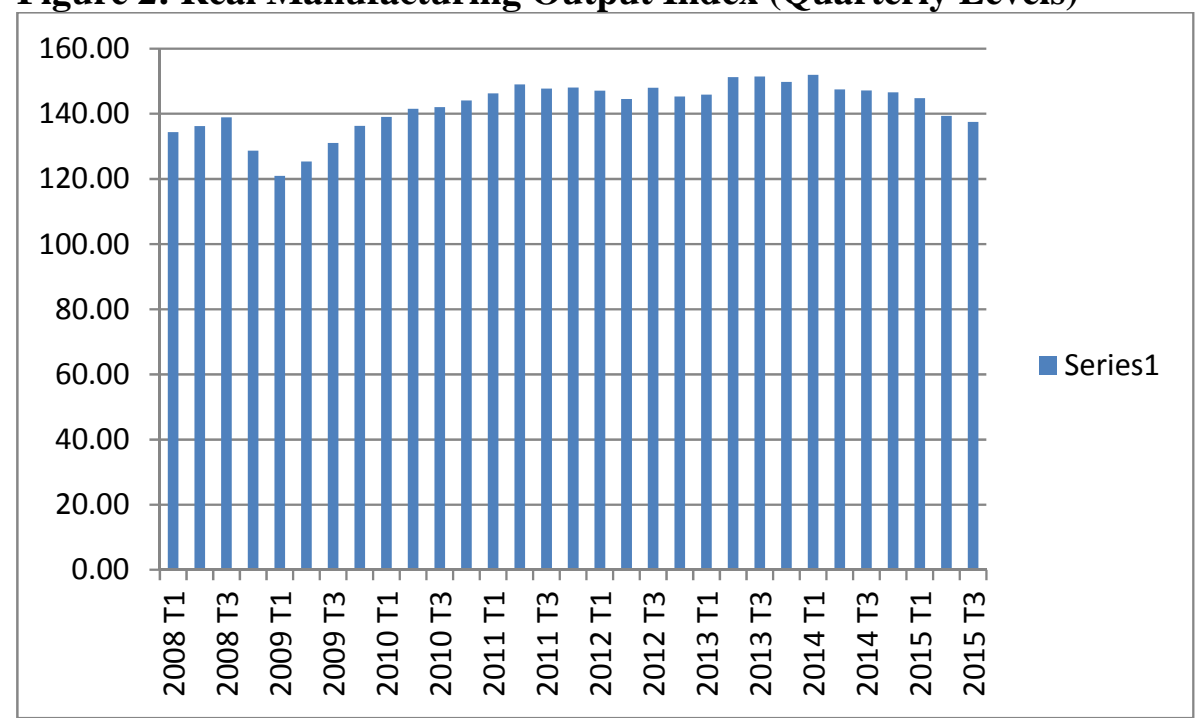

Source: Ipeadata

The manufacturing sector bore a large share of the burden of the price stabilization achieved by the Real Plan. Like other stabilization plans relying on cheap imports to keep domestic inflationary pressures in check, the Real Plan inevitably pushed for domestic currency overvaluation. In moments of crisis, this trend would be reversed as a result of bouts of capital flight, but "normalization" always brought back with it the overvaluation of the real. Sandwiched between high domestic interest rates, increased production costs, and an overvalued currency, Brazilian manufacturing saw its share in GDP fall sharply in the years after $1994 .{ }^{17}$ Many local producers were transformed into importers, many others sold their businesses to foreign firms, some simply closed their firms, and the rest survived but were always fighting to keep their market share under those adverse conditions. The overvaluation trend meant that classical expansionary macroeconomic policies were always more likely to lead to increased imports than to increased domestic industrial output. The government did

\footnotetext{
${ }^{16}$ Of course, it is always possible to argue that had the government chosen not to act the situation could be even worse.

${ }^{17}$ There are no reliable aggregate data about profits in Brazil. Profit estimates tend to be based on balance sheets of corporations, which, of course, bias the information toward larger businesses. For what it is worth, there is evidence of a strong fall in the share of corporate profits among non-financial firms. See, for instance, CEMEC (2015) graph 1, showing a fall in the net profits of manufacturing firms/GDP ratio from $1.38 \%$ in 2005 to $0.78 \%$ in 2014.
} 
implement expansionary policies, such as increasing the supply of consumer credit, particularly to lower-income households. A large share of it, with the overvalued currency, however, leaked into imports. Domestic producers could not compete in domestic as much as in international markets. Trying to support manufacturing businesses during Rousseff's first term, the government adopted supply policies aimed at reducing their costs. Subsidized credit and tax cuts were showered on businesses, to no great effect. ${ }^{18}$

Let us examine the GDP's behavior in a little more detail, by disaggregating output by demand categories.

We will use data on the gross formation of fixed capital to show the behavior of (public and private) investments in the period, as shown in figure 3. The output expansion observed after the 1999 balance of payments crisis did not lead to an expansion of investments, at least until 2004, when it finally began to grow at more significant rates. Expansion was interrupted, however, by the 2008 crisis. After that year, as it happened with output, there was initially a strong recovery that seemed to gradually lose steam until 2013 when it began a lasting contraction that extended to 2015.

Figure 3: Gross Formation of Fixed Capital Index (Quarterly Levels)

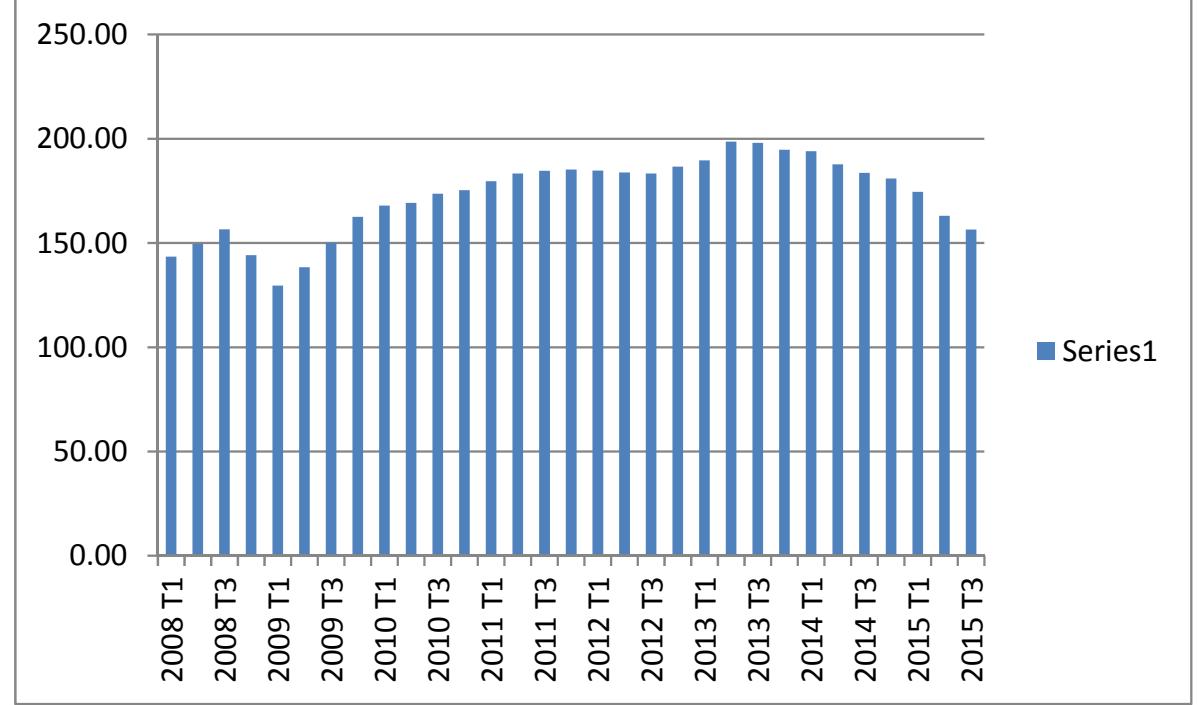

Source: Ipeadata

As one would expect, the trajectory of private consumption expenditures was less volatile. Growth was less spectacular, but the fall in 2009 was also less spectacular. The most

\footnotetext{
${ }^{18}$ A detailed list of government policies adopted between December of 2011 and June 2013 is given in IMF (2013, box 4, p. 12).
} 
important information offered by figure 4, however, is that after the crisis, consumption grew at decreasing rates until 2012, when a limit seems to have been reached. This is remarkable because the sharp increase in consumer credit was not only a favored instrument of economic recovery after 2009, but also because it was presented as an important instrument of social policy, giving lower-income families access to durable consumer goods.

Figure 4: Real Household Consumption Index (Quarterly Levels)

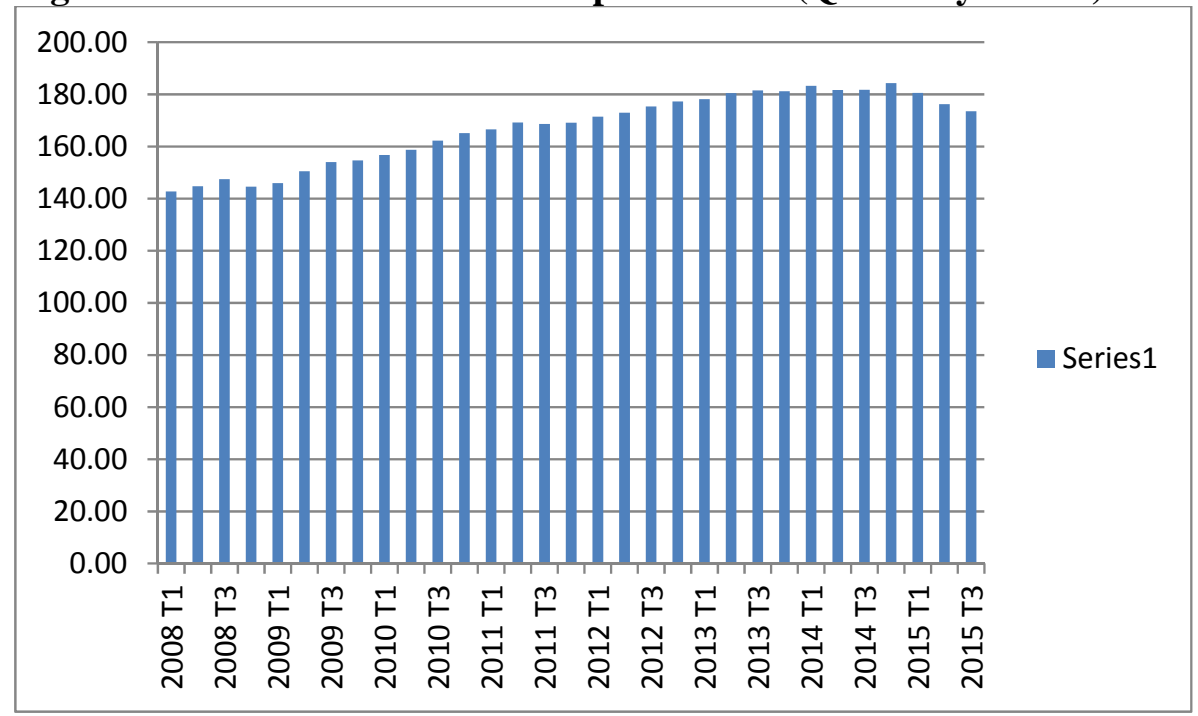

Source: Ipeadata

Government consumption, a measure of government current expenditures, has exhibited even less spectacular behavior. Although the usual caveats become especially significant when one examines recent data about fiscal expenditures in Brazil, what comes out in figure 5 is that current expenditures increased along a sustained linear trend until 2013, when they began to oscillate around their peak before decreasing slightly by the end of 2014 and increasing somewhat in 2015, although remaining below the peak. 
Figure 5: Real Government Consumption (Quarterly Levels)

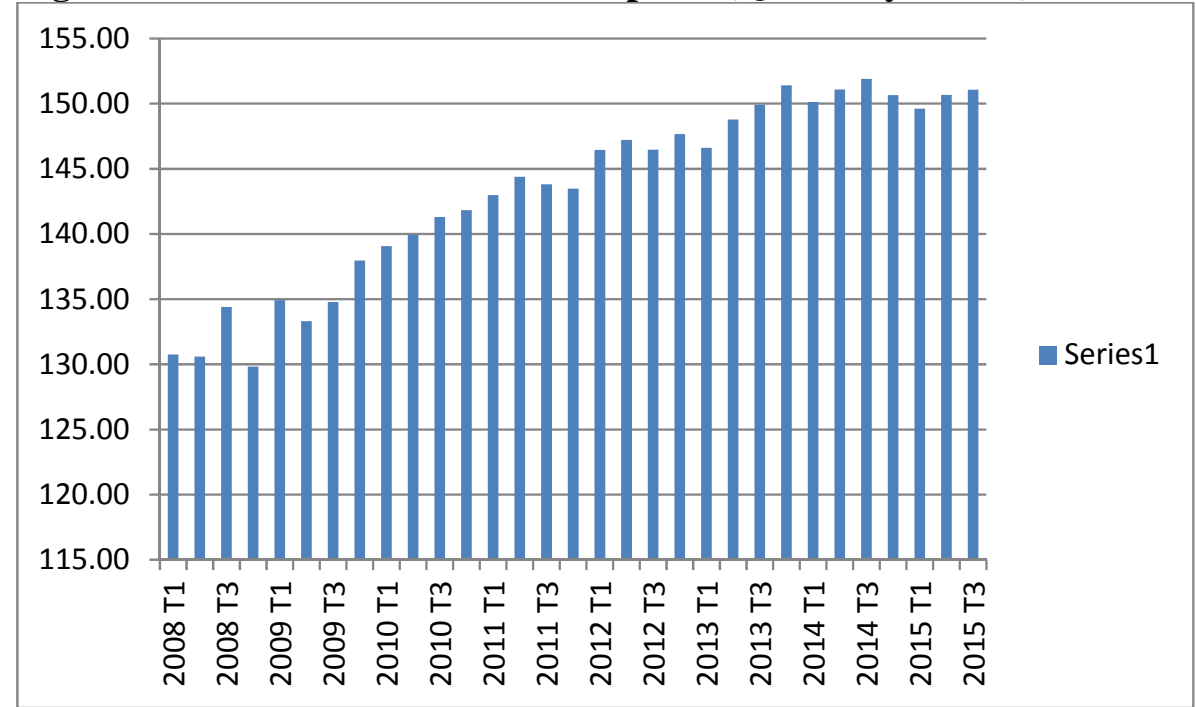

Source: Ipeadata

Finally, the last component of aggregate demand, net exports, behaved as one would expect knowing what happened to exchange rates in the period between the 1999 balance of payments crisis and the present. Overvalued exchange rates were an important element of inflation containment since the Real Plan in 1994. Overvaluation between 1994 and 1998 created imbalances in Brazil's balance of payments that led to the crisis in 1998/1999, which ended with a sharp devaluation of the real. Afterwards, the behavior of net exports is largely explained by real exchange rates and Chinese demand supported by the devaluation. The effect was further strengthened by another sharp devaluation in 2002. Predictably, exports reacted strongly to the stimulus. In addition, China's demand for raw materials helped support international prices for commodities and to absorb Brazilian exports. Imports, on the other hand, contracted at first in 2002 under the weight of the devaluation of the real. Soon enough imports recovered with the expansion of the economy plus the later resumption of the trend towards overvaluation. After the 2008 crisis, China's decision to reorient their growth strategy led to the stagnation of exports and helped change the sign of net exports from positive to negative. Only in 2015, when the recession broke the back of imports, did net exports become positive again following the example of other countries living through recessions, like Portugal or Spain. 
Figure 6: Exports and Imports Indices (Quarterly Levels)

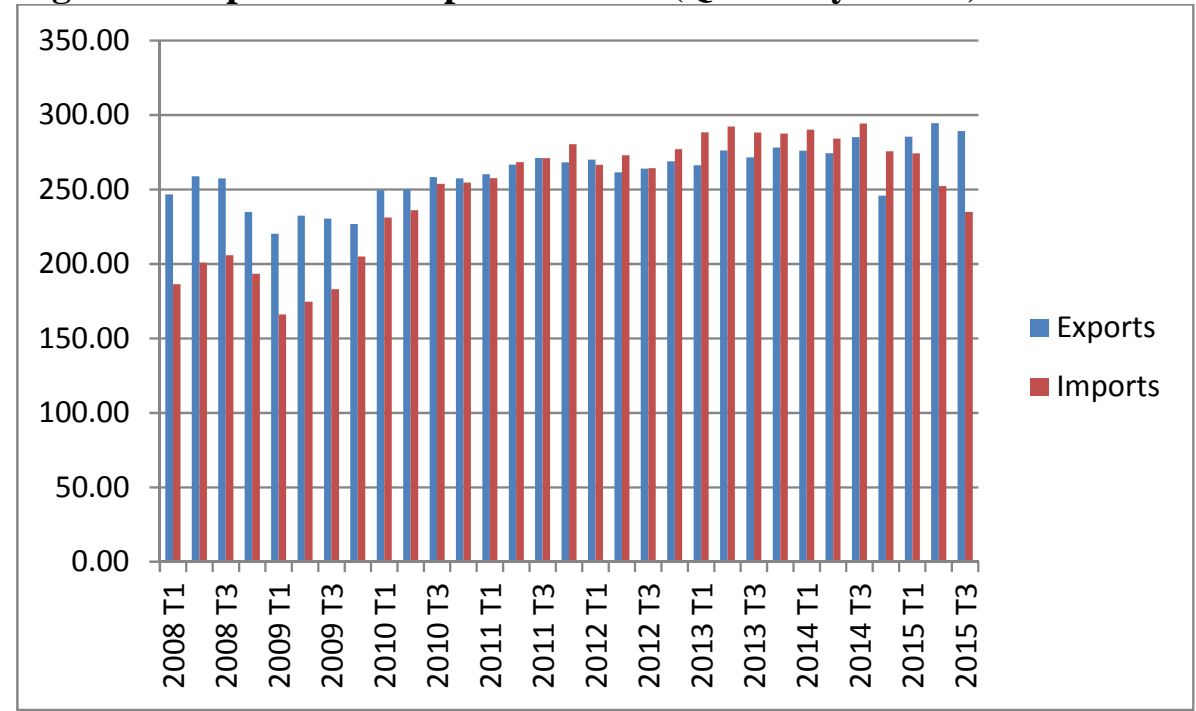

Source: Ipeadata

The deterioration of the trade position until 2014 coincided with a reversal in the behavior of nominal exchange rates. However, it also coincided with an increase in labor costs and a deterioration of inflation expectations, which may have reduced the efficacy of nominal devaluations in stimulating an acceleration of growth. In addition, according to many analysts, the long period of exchange rate overvaluation may have led to a wave of deindustrialization which would have reduced the size of the domestic manufacturing sector. If this is true, ${ }^{19}$ the subdued reaction even now to devaluation should be explained by the decimation of the sector that is usually the more sensitive to such forces. ${ }^{20} \mathrm{~A}$ final point also reminds us that in a situation of slow growth (or no growth at all) of international trade, increasing exports requires an increase in domestic productivity to complement devaluation. Productivity, however, had declined in the period. At the very end of the period, net exports became positive again, as noted, but in large part due to the cooling down of the economy and the resulting sharp fall in imports.

In sum, despite the expansionary character of government policies adopted in the post-2009 period, the Brazilian economy had lost steam for quite some time before Minister Levy took his post. Austerity policies, as will be discussed below, were certainly a factor in the contraction verified in 2015, but the fact remains that the economy was much more fragile at the beginning of 2015 than many were led to believe. The good times the country enjoyed

\footnotetext{
${ }^{19}$ This thesis is the object of intense controversy in Brazil.

${ }^{20}$ The concentration on exports of raw materials would, in addition, explain the low sensitivity of exports to exchange rate devaluations.
} 
during most of Lula da Silva's two terms in office, despite the 2009 recession, were explained much more by the Chinese pull and by abundant international liquidity than by enlightened policymaking. In fact, enlightened policymaking would have tried to take advantage of the good times to reduce the country's renewed dependence on exports of raw materials to one major buyer, thereby strengthening the domestic economy's foundations, but this was not even tried.

Overt manipulation of fiscal statistics, especially in 2014, makes it difficult to examine the stance of fiscal policy, but all evidence points to an expansionary drive, although it is still focused on the usual supply instruments. Inflation, on the other hand, fed mostly by supply shocks, was kept down as much as possible by manipulation of utilities prices. Success on both counts was poor, because, at least in the case of price manipulation, ample (negative) publicity was given to government interference.

The government also had to face the emergence of corruption scandals that were beginning to be revealed in 2014. The biggest of those scandals involved Petrobras. As a minister in Lula da Silva's cabinet, Rousseff was chairwoman of the administration board of Petrobras in the period in which many wrongdoings were supposed to have taken place. Although the president herself has not been identified as part of the corruption scheme, important questions arose with respect to her skills as a manager. ${ }^{21}$

The corruption scandals negatively impacted the Brazilian economy through direct and indirect channels. The direct impact was the dramatic reduction of investments they caused in Petrobras ${ }^{22}$ and in infrastructure projects, due to the wholesale indictment or conviction of practically all business leaders in the heavy construction industry.

The indirect impact was that the accumulation of accusations against current or former members of the government weakened Rousseff's hold on power, despite her reelection. The threat of impeachment proceedings against the president led her to desperate attempts to enlarge her base in Congress, including virtually giving up the prerogative of nominating ministers, shifting this presidential constitutional responsibility to the parties, etc. ${ }^{23}$

\footnotetext{
${ }^{21}$ A point that was made important by Lula da Silva's pitch in favor of his successor in the 2010 elections. He argued that what the country needed at that point was a manager as efficient as Rousseff was supposed to be.

${ }^{22}$ Petrobras has been responsible for about $10 \%$ of investment in Brazil.

${ }^{23}$ Even though many of them still voted against her projects in Congress.
} 
Rousseff's political loss with the corruption scandal was not her only problem. The change in her policy stance by announcing an austerity package after spending the whole electoral campaign declaring her opposition to it weakened her position even with her own political base. Talk about impeachment or annulment of the elections in fact began even before she was inaugurated for her second term. The political disintegration of the new government became crystal clear in the first quarter of 2015 when the impasse was made explicit: The president could not command enough political support to effectively govern and the opposition could not gather enough political support for shortening her term in office by legal means. ${ }^{24}$ It was clear to many that the country had suddenly become impossible to govern. ${ }^{25}$ Under such heightened uncertainty it should not come as a surprise that all important decisions by households and businesses were postponed and the economy gradually ground to a halt.

But the preceding considerations should not be construed as suggesting that austerity policies as such were completely off the hook as causes of the steep contraction in 2015. One can easily identify a contractionary "announcement effect” surrounding the first statements made by the appointed minister of finance by December 2014, which were reaffirmed after Rousseff's inauguration in January 2015. Some tough rhetoric was used by what the papers described then as the new strongman in the federal government. Nevertheless, the irresistible force of the new minister met the immovable object of Congress's opposition and was found wanting. ${ }^{26}$ Most policies were rejected out of hand. Some had their reach or intensity completely changed. Others were simply postponed to a discussion at an indefinite future date. In other words, the possible contractionary effect of announcing austerity policies was quickly replaced by the perception that perhaps no policy at all could be implemented by Rousseff's administration. ${ }^{27}$

\footnotetext{
${ }^{24}$ In fact, the situation was made even more complicated by the continuing investigation of corruption in the political system. Ongoing investigations and judicial proceedings are threatening both government and opposition leaders with the possibility of criminal indictments and jail terms. The political debate around policies and strategies got enmeshed, thus, in a parallel attempt to negotiate leniency deals or even the annulment of some of the accusations.

${ }^{25}$ With still more than three years to go before new elections will be held, in 2018.

${ }^{26}$ In fact, one cannot say that the majority of representatives in the Chamber of Deputies is actually constituted by Rousseff's opponents. However, even her supporters saw the chance of improving their bargaining power with the president in resisting the proposed policies.

${ }^{27}$ One dramatic example was the proposal to reintroduce a tax on payments made through the financial and banking system, known by its Portuguese acronym, CPMF. Opponents of the government declared their vote against the tax right away. Supporters of the government just postponed any decision. What was supposed to be an urgent need in the beginning of 2015 will possibly be examined at some point in 2016, with little chances of being approved.
} 
The public pressure on the federal government to harden its fiscal stance was maintained, or even increased, especially when the information became public about the extent to which fiscal accounting had been the subject of willful manipulation in recent years to show an improvement in performance. Unable to pass any legislation that could rationalize expenditures or increase revenues, the federal government appealed to the least-efficient method of austerity possible: self-imposed cuts in expenditures in the sectors least likely to put up significant resistance. The only significant policy change in the spending profile was the sharp cut in credit subsidies offered by public financial institutions, ultimately financed by the Treasury.

Table 2 shows how the federal government's fiscal expenditures evolved in 2015. Two remarks are in order. First, those are nominal values. One should remember that annual inflation was $10 \%$ and therefore real cuts were very significant. Second, the exceptionally high spending in December 2015 is in fact the result of an adjustment in intragovernmental accounts; under order of federal auditors, the government liquidated its debts with institutions such as the National Development Bank (BNDES) and the National Savings Bank (CEF). This liquidation is classified as government spending, but whatever expansionary impact it could have on the economy happened much earlier, when those banks lent money to private agents on behalf of the federal government. ${ }^{28}$

Table 2: Federal Government Expenditures

\begin{tabular}{|l|r|}
\hline & R\$ million \\
\hline 2014.12 & 98.019 \\
\hline 2015.01 & 92.545 \\
\hline 2015.02 & 77.529 \\
\hline 2015.03 & 81.153 \\
\hline 2015.04 & 89.154 \\
\hline 2015.05 & 85.294 \\
\hline 2015.06 & 89.376 \\
\hline 2015.07 & 98.181 \\
\hline 2015.08 & 83.947 \\
\hline 2015.09 & 89.350 \\
\hline 2015.10 & 99.006 \\
\hline 2015.11 & 95.584 \\
\hline 2015.12 & 169.147 \\
\hline
\end{tabular}

Source: Ipeadata

\footnotetext{
${ }^{28}$ If one excludes December values for 2014 and 2015, one arrives at total federal expenditures of R\$981,119 in 2015, only R \$48,053 more than what was spent from January to November of 2014, R\$933,066.

Expenditures by states and municipalities were hit even harder by the recession given their reduced power to determine their revenues.
} 
As fiscal policymakers were engulfed by paralysis, the only federal institution publicly perceived to be working was the central bank. An inflation rate way above the official target, however, forced the bank to raise overnight interest rates in the interbank reserves market, which reached $14.25 \%$ p.a. by the end of 2015 . The biggest loser from such a rise is, again, the Treasury, since an important share of public debt is indexed to the SELIC ${ }^{29}$ interest rate raised by the central bank.

In conclusion, there is clearly very limited, if any, political room for an expansionary policy to counteract the contraction being experienced since early 2015. By the turn of 2014 to 2015, the debate was whether Brazil would show the thesis of expansionary fiscal contraction to be correct, even after its own authors had disowned it (Perotti 2011, 2014). It was always very unlikely that confidence effects alone could successfully outweigh the negative multiplier effects of contractionary policies in avoiding the debacle witnessed in 2015 (and probably 2016). Like Italy, Brazil could be considered the ideal stage for such a test of that hypothesis, given the extraordinarily low confidence that surrounds the government's ability to steer the economy toward growth. But one has to remember that the thesis did not work even in Italy, and there would be no reason to assume it would perform better in the Brazilian case.

\section{A WAY OUT?}

Assuming that a solution for the political crisis could be found, is there any possible policy strategy that could stop the decline of the Brazilian economy?

The first matter of business must be to ensure that the devaluation of the real must endure, even if not necessarily at the higher levels it has reached in the beginning of 2016. Although it is not clear how far the recent devaluation will help in engineering a sustained recovery, there may be little doubt that a return to the overvaluation typical of the post-1994 period would probably kill any such possibility.

Even though it is not trivial, it should not be an impossible mission to keep the real around its current levels. The external value of the Brazilian currency has always been highly

\footnotetext{
${ }^{29}$ The Brazilian equivalent of the Federal Funds Rate.
} 
dependent on events taking place outside the country. Recently, two factors have been particularly important in the determination of exchange rates: monetary policy in the United States and sales of grains and raw materials to China.

Trend movements in the exchange rate closely followed the decisions made by the Federal Reserve in the years that followed the subprime crisis. Quantitative easing policies led to the most recent bout of overvaluation for the real. Devaluation began, on the other hand, when Fed Chairman Bernanke first raised the possibility of policy reversal. Although the pace of the tightening of monetary conditions in the United States is still uncertain, few analysts believe that there will be a return to the previous policy. Moreover, the attractiveness of emerging countries like Brazil to financial investors has been sharply decreased on account of domestic problems and the deceleration of growth in China.

Exporting agricultural and mineral commodities to China, as already noted, was the main cause of the rapid expansion of exports in the 2003-09 period. In fact, export revenues grew so strongly in that period that many analysts (most notably Luiz Carlos Bresser Pereira) revived the Dutch disease concept to show how those revenues were overvaluing the real and making it impossible for exporters of manufactured goods to remain competitive. The fall in Chinese growth rates and, perhaps even more important, the reorientation of its growth strategy, took the gas out of Brazilian commodity exports, again suggesting that the levels of the exchange rate observed recently may last for a rather prolonged period.

Finally, on the domestic side, one can argue that the central bank had reached its limits (or got very close to them) when it took overnight interest rates to a little over $14 \%$ p.a. by the end of 2014. Except for some economists connected to financial institutions, a large share of the economics community, orthodox and heterodox, is convinced that further increases would not make any difference in the fight against inflation but could compromise even more, perhaps fatally, the attempts to contain fiscal expenditures. A sharply devalued real could still attract a more intense capital inflow from investors chasing domestic assets at bargain prices. For the near future, however, political instability seems to have discouraged a large number of investors.

As already observed, the devaluation of the real per se may not, however, have the expected expansionary effect on the economy, at least for a while. A change in relative prices is 
expected to have a strong and immediate impact on competitiveness when capacity already exists and the only decision to make is how far to use it. After years of deindustrialization, some import substitution may take place, but expanding manufacturing output may be harder and take longer than one has seen in similar occasions in the past (e.g., in 1999). In addition, to stimulate investments in manufacture, businessmen have to believe the devaluation to be long-lasting. One obstacle in the way of reawakening animal spirits is stubbornly high inflation, which continuously erodes the gains obtained by devaluation.

So far, one can observe some signs of revival through small-scale import substitution, particularly by businesses that have started producing for themselves some of the components they need instead of importing them. The reaction of exports has been more subdued. International trade growth remains weak. Expanding exports requires dislodging some competitor, which is always more difficult than increasing shares of an expanding market. The recession has led to a sharp reduction in imports, on the other hand, which has increased net exports but does not signal, per se, a way out of the recession itself.

Domestic policymaking, therefore, has an essential but exceedingly difficult role to play in the present moment to end the recession and lead to recovery. High inflation and restricted fiscal policy space drastically limit the government's options. So far, government authorities seem to have chosen a cautious path, to avoid stirring things up in a period that is usually quiet in the country. The only important announcement referred to measures to increase credit supply, which one would expect to be hardly effective in the current situation. The problem is clearly not lack of credit but lack of demand. Households will probably not increase their debts, especially when facing the specter of unemployment. Businesses in need of credit are probably the ones trying to roll over current debts rather than seeking to finance new purchases of labor or raw materials, let alone investment goods. Private borrowers, households, and businesses who are already in debt and uncertain about future incomes would probably create an adverse selection problem whereby only those willing to take loans without caring for risks will present themselves in the market. Banks themselves may have second thoughts about increasing their exposure to indebted borrowers. ${ }^{30}$ In any

\footnotetext{
${ }^{30}$ Information published by the central bank in its "Financial Stability Report” of October 2015, suggests that banks did not yet have reasons to be concerned with non-performing loans. Graph 2.3.4, page 23, shows that non-performing loans of private banks remained fundamentally stable from early 2014 to mid-2015 (last information available), but well above the ratio observed in public banks in the same period. Of course, the information describes the period before unemployment began to increase and the economy accelerated its fall.
} 
case, scattered evidence coming from bank managers suggests that credit is already available but that there are no takers.

Austerity remains, officially, the chosen strategy, despite the deepening recession. One has to realize, however, that no other politically feasible strategy seems to exist. Corruption scandals on the one hand, repeated attempts to disguise the fiscal impacts of supply-side policies, and the generalized perception that government officials were managing public finances without any rationality or responsibility made classical expansionary policies impossible to be sold politically. High inflation, on the other hand, contributes to paralyzing any initiative in the direction of fiscal stimulation via willful generation of fiscal deficits.

Both Keynes and Kalecki suggested that relying on private agents to promote a recovery from a normal recession (let alone a deep recession like the one Brazil is going through) is a mistake. To expect consumers to increase their debts to spend on consumption when rising unemployment is a concrete threat and there are signs that current loans are already hard to liquidate seems hopeless.

Any revival of aggregate demand has to come from investments, but it is also difficult to see why private businesses would increase investment when there is no prospect of fully utilizing the equipment they already have.

Investments, therefore, have to come from "outside," on the initiative of either the government or foreign investors, or both in concert. The obvious destination is investment in infrastructure, of which the country is in dire need. ${ }^{31}$

Joint projects with foreign investors, public/private partnerships (PPPs) for instance, are one possibility, although such partnerships may be more difficult to create than is usually supposed. How to define the roles and rights of each party to the partnership is not a trivial problem to solve, and both governments and private investors are usually suspicious of each other. Besides, in many PPPs, the government builds and private investors manage the facilities by concession or other form of contract. This type of solution would not be helpful

\footnotetext{
${ }^{31}$ Both Keynes and Kalecki insisted on the importance of public investment as the initiator of a recovery; see Keynes (1982: 148, 151, 158) and Kalecki (1971: ch 2 and 3).
} 
since the current situation is characterized precisely by the difficulty the federal government faces in increasing its expenditures.

The alternative that seems to be left is for government itself to take the initiative, but by compensating for these expenditures with cuts in other expenditures that have a lower power to result in multiplied income. It is well-known that investments are more efficient than fomenting consumption in this aspect, since part of the increase in consumers' income will leak into increased saving, while investment is entirely spent. Spending in the form of subsidies is even less efficient in increasing output and employment. Public works and infrastructure investments - usually the expenditures that are sacrificed when there are proausterity pressures - should be precisely the priorities when there is need to revive the economy. If total expenditures cannot be increased, it is the other items of government spending that should shoulder the cuts.

\section{POLITICAL OBSTACLES}

The proposal to increase public investments, at the cost of other expenditures, takes us back full circle, to the political crisis. Reducing fiscal deficits while increasing investments requires either raising taxes or cutting other expenditures or, more likely, a combination of both. Even in the best political conditions, it is certainly a difficult equation to solve. If it is decided to raise taxes, which taxes should be increased and who would pay them? If expenditures are to be cut, which ones should be reduced?

Again, the Brazilian situation seems impossible. No group accepts the idea of higher taxes, unless other people are chosen to shoulder them. No group, on the other side, accepts a cut in those expenditures of which they are the beneficiary. In fact, in the post-military regime period, the practice of earmarking fiscal revenues to specific expenditure items has been widespread. Some of this earmarking even became constitutional provisions. Only skillful political negotiation led by trusted political leadership could obtain current sacrifices from the participants with a view to achieving better results in the future. Unfortunately, there does not seem to exist the slightest possibility that such a negotiation could happen in the near future. The government does not seem capable of doing it. All initiative was lost when avoiding or beating an impeachment process became its first and practically only priority. 
On the other hand, there is no legitimate organized opposition to present demands and lead a negotiation on behalf of the people. The country has no "elders" to appeal to, no statesmen of recognized stature to deserve the trust of the nation.

Under such circumstances, there seems to be no alternative to the continuation of the recession and political uncertainty until the country gets closer to the presidential elections scheduled for 2018. 


\section{REFERENCES}

Banco Central do Brasil. 2015. “Relatório de Estabilidade Financeira.” Publicação semestral do Banco Central do Brasil 14(2): 1-69.

Cardim de Carvalho, F. 1993. "Strato-inflation and high inflation: the Brazilian experience.” Cambridge Journal of Economics 17(1): 63-78.

Centro de Estudos do IBMEC (CEMEC). 2015. "Câmbio Contribui para Recuperação de Margens e Competitividade da Indústria.” Nota CEMEC 06/2015.

Feijo, C., and F. Cardim de Carvalho. 1992. "The resilience of high inflation: recent Brazilian failures with stabilization policies.” Journal of Post Keynesian Economics 15(1): 109-24.

Frenkel, R. 1979. Decisiones de Precios en Alta Inflacion. Buenos Aires: Estudios CEDES 6.

International Monetary Fund (IMF). 2013. Staff Report for the 2013 Article IV Consultation, IMF Country Report 13/312, October.

—. 2016. World Economic Outlook Update, January 19.

Kalecki, M. 1971. Selected Essays on the Dynamics of the Capitalist Economy. Cambridge: Cambridge University Press.

Keynes, J.M. 1982. Activities 1931-1939. World Crises and Policies in Britain and America, The Collected Writings of John Maynard Keynes, vol.XXI, edited by D. Moggridge. London: MacMillan and Cambridge: Cambridge University Press.

Kregel, J. 2009. “The global crisis and the implications for developing countries and the BRICS: is the 'B' really justified?” Brazilian Journal of Political Economy 29(4): 341-56.

Perotti, R. 2011. “The ‘Austerity Myth’: Gain Without Pain?” BIS Working Papers 362.

— 2014. "Fiscal Policies in Recession.” in Akerlof, G. et alli (eds), What Have We Learned? Macroeconomic Policy After the Crisis. Cambridge: MIT Press.

Sylos-Labini, P. 1984. The Forces of Economic Growth and Decline. Cambridge: MIT Press. 